\title{
PENGARUH TINGKAT KESADARAN MASYARAKAT DALAM PERENCANAAN KEUANGAN KELUARGA TERHADAP KESEJAHTERAAN (Studi pada Warga Komplek BCP, Jatinangor)
}

\author{
Fitria Adi Wulandari \\ Rosemarie Sutjiati \\ Universitas Kristen Maranatha \\ rosemarie.sutjiati@yahoo.com
}

\begin{abstract}
This study describes the financial planning done by the people of Komplek Bumi Cipacing Permai (BCP), The research was preceded by a pre - survey to several communities in Komplek Bumi Cipacing Permai (BCP), that people have been doing financial planning, but not in detail which the community only list a source of revenue after expenses list. The problem is each month sometimes there are a lot of unexpected expenses. Therefore, it needs good management, in order to be a prosperous family. This study used a descriptive method with quantitative approaches through questionnaires distributed to 230 respondents from residents Komplek BCP, jatinnagor. Data were analyzed using Validity and Reliability, Test Normality and Simple Regression Testing. This study examines the effect of the level of public awareness on the welfare of the family 's financial planning. The results of simple regression analysis shows that the variables affect the well-being.
\end{abstract}

Keywords: Investments, Financial Planning, Family, and Wellbeing

\begin{abstract}
Abstrak
Penelitian ini menggambarkan perencanaan keuangan yang dilakukan oleh masyarakat di Komplek Bumi Cipacing Permai (BCP). Penelitian ini dimulai dengan survey awal ke beberapa komunitas di Komplek Bumi Cipacing Permai (BCP), yang telah melakukan perencanaan keuangan, tetapi tidak secara rinci dimana mereka hanya mendaftar sumber pendapatan dibandingkan daftar pengeluaran. Masalahnya adalah setiap bulan kadang-kadang ada banyak biaya tak terduga. Oleh karena itu diperlukan manajemen yang baik, agar terbentuk keluarga sejahtera. Penelitian ini menggunakan metode deskriptif dengan pendekatan kuantitatif melalui kuesioner yang disebarkan kepada 230 responden dari warga Komplek BCP, jatinnagor. Data dianalisis dengan menggunakan Validitas dan Reliabilitas, Uji Normalitas dan regresi sederhana. Penelitian ini menguji pengaruh tingkat kesadaran masyarakat terhadap kesejahteraan perencanaan keuangan keluarga. Hasil analisis regresi sederhana menunjukkan bahwa variabel-variabel perencanaan keuangan mempengaruhi kesejahteraan.
\end{abstract}

Kata kunci: investasi perencanaan keuangan , keluarga, dan kesejahteraan

\section{PENDAHULUAN}

Warsono (2010) menyatakan Indonesia dengan jumlah penduduk saat ini sebanyak 231 juta orang, sebagian besar masih menghadapi kendala dalam kesejahteraan hidup. Hal ini dapat dilihat dari indikasi pendapatan per kapita masyarakat yang baru mencapai sebesar US\$2600. Dengan pendapatan per kapita se- besar itu, perlu pengelolaan yang baik, sehingga dapat mengoptimalkan pengalokasiannya. Di samping itu penggunaan sumber pembelanjaan, pengelolaan risiko, dan penyiapan dana pensiun yang tepat perlu dipikirkan lebih mendalam. Menurut Taufik Hidayat (2010) perencanaan keuangan atau Financial Planning adalah proses merencanakan keuangan untuk mencapai tujuan keuangan. 
Menurut Rodhyah (2012), uang menjadi sangat penting karena merupakan salah satu alat bayar, alat memupuk kekayaan, maupun alat untuk berjaga-jaga. Begitu pentingnya uang dalam peradaban manusia modern, sehingga uang bisa menjadikan orang menjadi bahagia dan juga bisa menjadi sumber malapetaka, sehingga banyak terjadi keluarga menjadi bercerai-berai dan muncul masalah keluarga karena uang. Keluarga dikatakan sejahtera ketika keluarga dapat menikmati hidup yang wajar, tercukupi kebutuhan materiil maupun spiritual dan semua anggota keluarga mendapat kesempatan seluasluasnya untuk berkembang.

Pentingnya uang dalam kehidupan manusia khususnya keluarga adalah tidak hanya banyaknya jumlah uang yang dimiliki, tetapi juga bagaimana memanfaatkan uang yang diperoleh untuk mencapai kesejahteraan keluarga. Menurut Warsono (2010), dalam rangka mencapai kemerdekaan keuangan, pengetahuan dan implementasi atas praktik keuangan yang sehat, idealnya perlu dipunyai dan dilakukan oleh setiap orang. Sejauhmana pengetahuan dan implementasi seseorang atau masyarakat dalam mengelola keuangan ini sering dikenal sebagai literasi (kemelekan) keuangan (financial literacy). Tingkat literasi keuangan seseorang dapat dilihat dari sejauhmana dia dalam mendayagunakan sumberdaya keuangan, menentukan sumber pembelanjaan, mengelola risiko jiwa dan aset yang dimilikinya, dan mempersiapkan keamanan sumberdaya keuangan di masa mendatang apabila sudah tidak bekerja (pensiun).

Hal buruk yang mungkin akan terjadi di masa yang akan datang dapat diatasi dengan cara melakukan perencanaan keuangan, maka di perlukan suatu perencanaan keuangan sejak dini. Perencanaan dibuat untuk mengantisipasi hampir semua kemungkinan yang terjadi. Perencanaan diperlukan agar masyarakat dapat mencapai tujuan keuangan secara menyeluruh dan mencakup seluruh siklus kehidupan, dari sekarang hingga akhir nanti. Tanpa perencanaan yang benar dan matang, bisa terjadi kekacauan dalam keuangan. Hal ini juga membutuhkan disiplin dan kontrol yang tepat.

Perencanaan keuangan keluarga tidak hanya diperuntukkan bagi mereka yang berpendapatan besar, setiap orang baik kaya atau miskin perlu untuk membuat perencanaan hidupnya guna mewujudkan tujuan hidupnya, namun yang berbeda hanyalah dalam pengalokasian pengelolahan uang. Wibawa (2003), menyatakan diperlukan perencanaan keuangan karena semua orang pada dasarnya memiliki ketidakpastian yaitu ketakutan akan masa depan kehidupan finansial, karena pada hakekatnya hidup adalah ketidakpastian dan tidak ada seorangpun yang mampu untuk mencegah kecelakaan, penderitaan dan kesukaran serta mengejar keberuntungan dan nasib baik. Dengan perencanaan keuangan akan memberikan pilihan untuk menghadapi masa depan.

Pentingnya perencanaan keuangan ini sudah dirasakan betul oleh kebanyakan masyarakat kita, tapi belum mengetahui bagaimana penerapan mereka akan perencanaan keuangan ini. Banyak dari masyarakat kita juga masih berfikiran secara tradisional dengan meletakkan seluruh pendapatannya dibawah bantal dan apabila terdapat keperluan baru dana tersebut dikeluarkan dan dengan sikap seperti ini masyarakat tersebut tidak dapat memilah-milah mana pengeluaran yang harus diprioritaskan, untuk tujuan jangka panjangnya, dan bagaiman untuk keadaan-keadaan darurat, mereka kurang memikirkannya (Rahmawati D. P., 2010). Sebelum melakukan perencanaan keuangan, masyarakat perlu memahami mengenai instrumen keuangan terlebih dahulu. Pada saat ini, banyak produk-produk yang ditawarkan oleh lembaga-lembaga keuangan, untuk perencaan keuangan yang baik untuk tujuan jangka pendek, menengah dan jangka panjang. Semua itu ditujukan agar masyarakat mudah dalam mengelola keuangan dan membantu dalam perencanaan keuangan yang diinginkannya. Selain itu, pada saat sekarang ini banyak masyarakat yang belum benar-benar mengerti bahwa penempatan dana di bank dan lembaga keuangan pada instrumen Keuangan atau pada sektor selain keuangan yang tepat sudah merupakan perencanaan keuangan berupa investasi.

Alasan mengambil Komplek Bumi Cipacing Permai (BCP) di Jatinangor dalam penelitan ini adalah karena masyarakatnya memiliki pendapatan yang beragam, juga pengetahuan masyarakat di wilayah komplek mengenai perencanaan keuangan mungkin sudah lebih baik. Hal ini dilihat ketika peneliti melakukan pra-survey kepada beberapa masyarakat di Komplek Bumi Cipacing Permai (BCP), bahwa sebagian besar masyarakat telah 
melakukan perencanaan keuangan, tetapi tidak secara detail sesuai dengan prosedur perencanaan keuangan keluarga. Masyarakat hanya melakukan perincian sumber pendapatan setelah itu membuat daftar pengeluaran. Masalahnya, pengeluaran keuangan masyarakat pada tiap bulannya terkadang banyak pengeluaran diluar dugaan yang diperkirakan. Sehingga ketika terjadi hal yang tidak terduga dan membutuhkan pengeluaran dana yang tidak diperkirakan. Kebanyakan dari masyarakat menjadi bingung karena keuangan untuk hal tersebut tidak tersedia, sedangkan keuangan mereka telah digunakan dan dialokasikan untuk keperluan-keperluan lainnya sehingga tidak ada lagi dana untuk hal yang tidak terduga.

\section{KAJIAN PUSTAKA}

\section{Tingkat Kesadaran Masyarakat}

Menurut Kamus Besar Bahasa Indonesia Pusat Bahasa (2008), kesadaraan adalah keinsafan, keadaan mengerti hal yang dirasakan atau dialami oleh seseorang. Tingkat adalah lapisan dari sesuatu yang bersusun atau berlenggeklenggek: tinggi rendah, pangkat, derajat, taraf, dan kelas. Masyarakat adalah sehimpunan manusia yang hidup bersama dalam suatu tempat dengan ikatan-ikatan aturan tertentu. Jadi, tingkat kesadaran masyarakat adalah susunan yang berlapis-lapis mengenai kadar keinsafan dan keadaan mengerti hal yang dirasakan atau dialami oleh sehimpunan manusia yang hidup bersama dalam suatu tempat dengan ikatan-ikatan aturan tertentu.

\section{Perencanaan Keuangan}

Perencanaan Keuangan secara definisi menurut Certified Financial Planner, Board of Standards, Inc. (2007), adalah proses mencapai tujuan hidup seseorang melalui manajemen keuangan secara terencana. Tujuan hidup dapat termasuk membeli rumah, menabung untuk pendidikan anak atau merencanakan pensiun (Indrasto B. \& Gunanto, 2010).

Menurut Taufik Hidayat (2010), perencanaan keuangan atau financial planning adalah proses merencanakan keuangan untuk mencapai tujuan keuangan. Satu alasan pasti mengapa kita harus melakukan financial planning adalah karena kita harus menjalani kehidupan yang sudah diberikan Tuhan. Saat menjalani kehidupan, ada banyak sekali hal yang harus dilakukan dalam kondisi ketidakpastian. Dan untuk itulah kita memerlukan perencanaan yang benar.

Menurut Aulia (2009), Proses perencanaan keuangan terdiri dari 5 prosedur yang logis, dengan urutan sebagai berikut:

\section{Menentukan tujuan keuangan}

Menentukan tujuan keuangan dengan SMART (Spesifik, Measurable, Achievable, Realistik dan Time-Frame). a). Spesifik artinya kita harus dapat membayangkan tujuan kita secara detail. Misalkan untuk dana pendidikan anak, kita harus sudah dapat memperkirakan ke universitas mana anak kita akan mengambil gelar sarjana. Untuk dana pensiun kita harus sudah dapat membayangkan bagaimana kehidupan yang kita inginkan pada saat kita tua nanti. b). Measurable artinya dapat diukur, dalam hal ini alat ukurnya adalah mata uang. Misalkan saja kita ingin membuat rencana untuk liburan akhir tahun, kita harus memperkirakan berapa banyak uang yang akan dibutuhkan untuk liburan kita nanti. c). Achievable berarti dapat kita capai. Agar tidak menjadi pungguk yang merindukan bulan, sebaiknya tujuan keuangan disesuaikan dengan kemampuan keuangan kita. d). Realitik berarti tujuan kita masuk akal, bukan merupakan khayalan yang tidak dapat diwujudkan dalam dunia nyata. e) Time Frame berarti kita harus memiliki jangka waktu yang jelas untuk mencapainya. Misalkan saja untuk dana pendidikan anak, kita harus tahu jelas kapan sang anak akan masuk ke universitas. Untuk rencana pensiun kita harus tahu pada umur berapa kita akan pensiun.

\section{Menganalisa kondisi keuangan sekarang}

Setelah merumuskan tujuan keuangan yang ingin dicapai, tahap selanjutnya adalah kita harus mengetahui posisi keuangan kita saat ini. Langkah-langkah yang diperlukan untuk menganalisis kondisi keuangan sekarang adalah: Membuat laporan kekayaan bersih (neraca) dan laporan arus kas.

a). Laporan Kekayaan Bersih (Neraca). Hasil pengurangan antara jumlah harta dengan jumlah hutang dikenal dengan nama kekayaan bersih. Laporan Kekayaan Bersih merupakan potret dari kondisi keuangan seseorang pada saat itu. Dalam kondisi normal, nilai kekayaan 
bersih seseorang adalah: $=($ Usia $\mathrm{x}$ penghasilan tahunan)/10, jika setelah dihitung, ternyata nilai kekayaan bersih seseorang berada di bawah (Usia $\mathrm{x}$ penghasilan tahunan/10) ini berarti orang tersebut belum dapat mengelola keuangan pribadinya dengan baik dan disarankan untuk menghubungi perencana keuangan untuk mendapatkan konsultasi mengenai caracara mengelola keuangan.

b). Laporan Arus Kas. Secara umum laporan arus kas terdiri dari 2 bagian, yaitu Arus Kas Masuk (pendapatan), dan Arus Kas Keluar (pengeluaran). Pada bagian Arus Kas Masuk, kita menuliskan pendapatan-pendapatan kita seperti gaji, tunjangan, bonus, atau mungkin ada pendapatan dari pekerjaan sampingan. Sementara pada Arus Kas Keluar terdiri dari 3 bagian. Bagian pertama adalah pengeluaran untuk tabungan atau investasi. Bagian keduanya adalah pengeluaran untuk biaya tetap (biaya yang setiap bulan harus kita bayar dalam nilai yang sama), misalnya KPR, KPM, iuran TV, Premi Asuransi, dan lain-lain. Sementara bagian ketiga adalah pos-pos pengeluaran kita seperti makanan, pakaian, transportasi, hiburan, kesehatan, pendidikan, pembayaran kartu kredit dan lain-lain. prinsip dasar dari keuangan adalah "Pendapatan harus lebih besar daripada pengeluaran".

c). Melakukan analisis Rasio Keuangan. Setelah membuat kedua jenis laporan diatas, dapat dilakukan analisa terhadap kondisi keuangan kita melalui rasio-rasio keuangan. Ada 8 buah rasio yang lazim digunakan dalam menganalisis keuangan pribadi ataupun keluarga, yaitu: Rasio Likuiditas, Rasio Aset Likuid terhadap Kekayaan Bersih, Rasio Tabungan, Rasio Perbandingan Nilai Bersih Aset Investasi terhadap Nilai Bersih Kekayaan, Rasio Perbandingan Hutang Terhadap Asset, Rasio-rasio Kemampuan Pelunasan Hutang, Rasio Rasio Kemampuan Pelunasan Hutang Non Hipotek, dan Rasio Solvabilitas. Rasiorasio ini dapat mendeteksi penyakit-penyakit finansial seperti: Resiko kekurangan uang kas, terlalu banyak hutang , terlalu boros atau terlalu pelit, dan gejala kebangkrutan. Jadi disini yang perlu diingat adalah bahwa dalam mengelola keuangan, kita harus bisa menyisihkan sebagian pendapatan untuk digunakan di masa depan. Minimal adalah 10\%. Namun, disisi lain, kita juga harus bisa menikmati uang yang telah berhasil didapatkan. Jangan semuanya disimpan buat masa depan. Jadi nilai maksimal yang sebaiknya ditabung adalah $30 \%$ dari total pendapatan Anda.

\section{Membuat rencana keuangan}

Dua langkah yang harus dilakukan dalam membuat rencana keuangan yaitu: a). Membuat Anggaran Pendapatan Pengeluaran Pribadi/Keluarga. Secara umum anggaran terbagi 2 bagian, yaitu pendapatan dan pengeluaran. Setelah menyusun daftar pendapatan yang dapat diperoleh kemudian memberi jatah pengeluaran untuk masing-masing pos pengeluaran yang telah disusun dan jangan lupa untuk memasukkan tabungan dan investasi untuk pos pengeluaran. b). Membuat rencana keuangan untuk mencapai tujuan-tujuan keuangan yang telah kita rumuskan sebelumnya dengan berinvestasi menggunakan konsep compound interest.

\section{Melakukan implementasi dari rencana keuangan}

Dalam melakukan implementasi dari rencana keuangan, kepribadian seseorang terhadap risiko memengaruhi pemilihan produk investasi. Bagi yang merasa tidak cocok dengan risiko, lebih baik memilih investasi dengan risiko menengah kebawah. Namun bagi yang berani menanggung risiko, boleh memilih investasi yang agresif dengan risiko yang tinggi pula.

\section{Monitor dan evaluasi berkala}

Secara berkala, lakukan monitor dan evaluasi kembali terhadap rencana-rencana keuangan yang telah dijalankan. Monitor berguna untuk memastikan bahwa investasi berjalan sesuai dengan rencana kita, dan apabila ternyata tidak, kita dapat mengambil tindakan secepatnya agar tujuan keuangan tetap dapat tercapai. Sementara evaluasi perlu dilakukan karena kebutuhan kita bisa saja berubah seiring dengan jalannya waktu.

\section{Perencanaan keuangan keluarga}

Menurut Aulia (2009), pada prinsipnya sebuah perencanaan keuangan adalah untuk membantu dan memudahkan setiap keluarga dalam menentukan regulasi keluar masuknnya uang dalam keluarga. Fungsi dari perencanaan keuangan keluarga adalah merencanakan masa depan sedini mungkin untuk mencapai tujuan 
keuangan yang dicita-citakan melalui pengelola keuangan yang terencana, teratur dan bijak. Dengan adanya perencanaan keuangan, kita bisa mengontrol kondisi keuangan kita sekarang dan hari esok. Akan tetapi pada kenyataannya, di Indonesia masih sangat sedikit keluarga yang sudah menyusun rencana keuangannya, adapun faktor-faktor penyebabnya antara lain: 1). Kesadaran masyarakat yang rendah. Perencanaan keuangan hanyalah untuk orang kaya, begitu persepsi dari sebagian masyarakat. Padahal menjadi "kaya" adalah hasil dari proses perencanaan keuangan. 2). Tidak mempunyai tujuan keuangan yang jelas. Tidak ada visi masa depan menyebabkan kita bersikap mementingkan kebutuhan jangka pendek saja. Cenderung menghabiskan uang untuk memenuhi keinginan jangka pendek semata. 3). Keterbatasan waktu. Pentingnya melakukan perencanaan keuangan baru dirasakan ketika kebutuhannya sudah di depan mata. Inilah yang menyebabkan masih banyaknya keluarga yang menganggap biaya pendidikan sebagai "biaya tak terduga" dan terpaksa harus berutang untuk itu. 4). Keterbatasan ilmu dan pengetahuan bagaimana mengelola keuangan keluarga yang baik. Pada jenjang pendidikan manapun, pada konsentrasi keilmuan apapun, lembaga pendidikan formal di Indonesia belum mengajarkan materi mengenai keuanagan keluarga. 5). Belum mampu memilih produk keuangan yang semakin beragam. Makin banyaknya produk keuangan tidak diimbangi dengan sosialisasi, edukasi, dan infrastruktur yang merata. Produk keuangan tertentu bahkan berkesan hanya untuk kalangan ekonomi atas, atau yang tinggal di kota besar saja.

\section{Kesejahteraan}

Menurut Kamus Besar Bahasa Indonesia Pusat Bahasa (2008), kesejahteraan adalah hal atau keadaan sejahtera, keamanan, keselamatan, ketentraman, kesenangan hidup, dan kemakmuran. BKKBN (1994), mengkonsepkan perkembangan kesejahteraan masyarakat desa sebagai ukuran kesejahteraan keluarga/taraf hidup masyarakat, terdiri dari 5 (lima) tingkat kesejahteraan, yaitu: 1) Keluarga Prasejahtera; yaitu keluarga yang belum dapat memenuhi kebutuhan dasar minimum seperti kebutuhan pangan, sandang, papan dan kesehatan. 2) Keluarga Sejahtera I, yaitu keluarga yang telah dapat memenuhi kebutuhan dasar minimum, tetapi belum dapat memenuhi keseluruhan kebutuhan sosial psikologisnya seperti: pendidikan, interaksi dalam keluarga, interaksi dengan lingkungan tempat tinggal, dan transportasi. 3) Keluarga Sejahtera II, yaitu keluarga yang disamping telah dapat memenuhi kebutuhan dasar minimal, juga kebutuhan sosial psikologisnya, tetapi belum dapat memenuhi kebutuhan berkembang/perkembangannya seperti menabung, memperoleh informasi, transportasi, dan sebagainya. 4) Keluarga Sejahtera III, yaitu keluarga yang telah dapat memenuhi seluruh kebutuhan dasar minimal, kebutuhan sosial psikologis, dan kebutuhan perkembangan, namun belum dapat berpartisipasi maksimal terhadap masyarakat baik dalam bentuk sumbangan material, keuangan, ikut serta secara aktif dalam kegiatan sosialkemasyarakatan, dan sebagainya. 5) Keluarga Sejahtera III-Plus, yaitu keluarga yang telah dapat memenuhi seluruh kebutuhannya baik kebutuhan dasar minimal, kebutuhan sosial psikologis, maupun yang bersifat perkembangan serta telah dapat memberikan sumbangan nyata dan berkelanjutan, bagi masyarakat atau pembangunan.

Pada saat ini tingkat kesadaran masyarakat dalam merencanakan keuangan keluarga sudah tergolong baik, hal ini dapat dilihat dari sebagian besar masyarakat yang telah melakukan perencanaan keuangan, tetapi belum sesuai dengan prosedur perencanaan keuangan keluarga.

Rahmawati (2010) menjelaskan bahwa kesadaran masyarakat adalah suatu hal yang berkaitan dengan nilai-nilai yang tumbuh dan berkembang dalam masyarakat, dan sesuai dengan itu maka indikator-indikator kesadaran masyarakat dalam perencanaan keuangan, adalah pengetahuan dan pemahaman tentang perencanaan keuangan, pengetahuan dan pemahaman tentang investasi yang membantu dalam merencanakan keuangan, sikap dalam merencanakan keuangan, dan perilaku dalam merencanakan keuangan. 
Kerangka Pemikiran

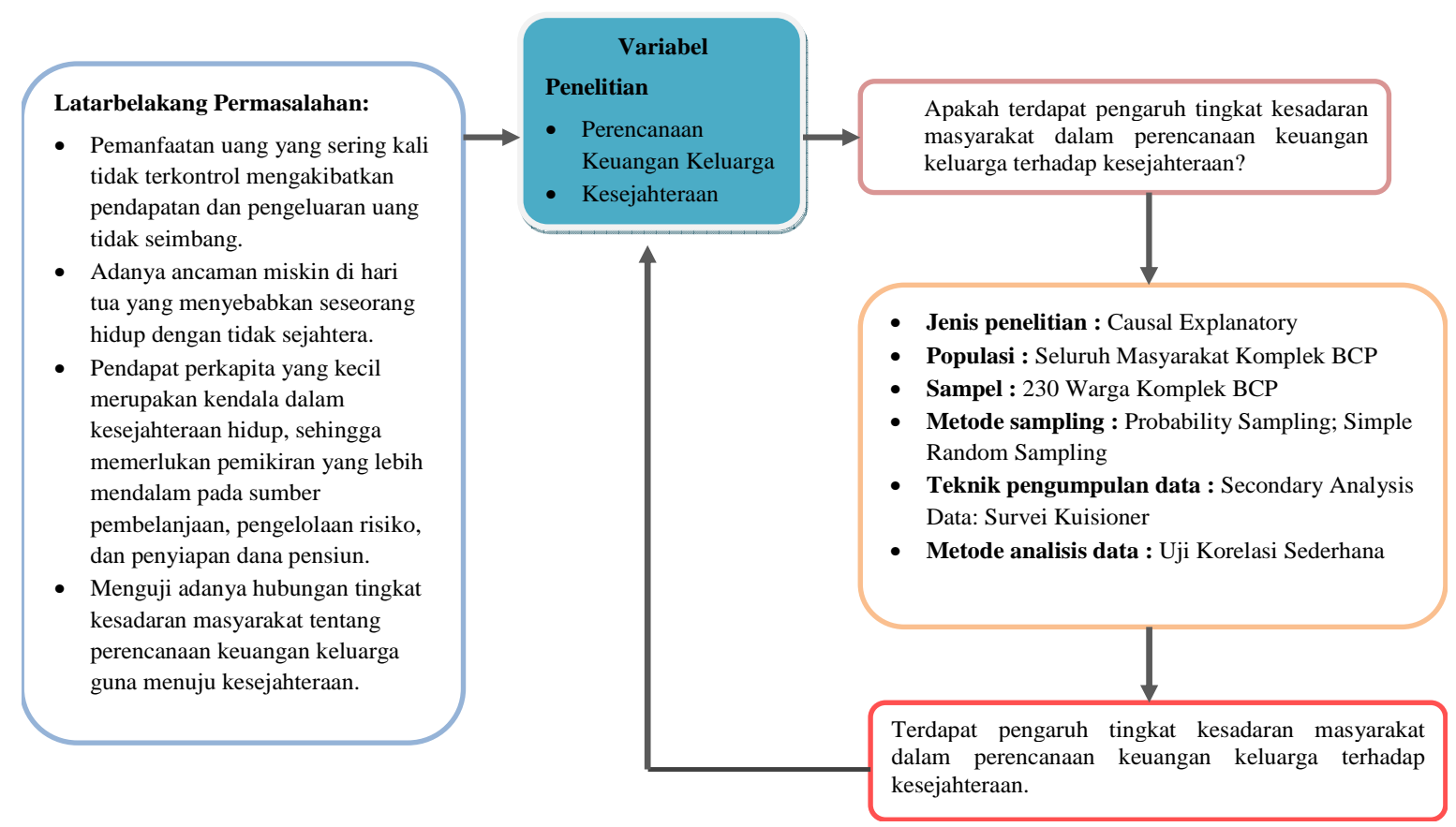

\section{Pengembangan Hipotesis}

Penelitian yang dilakukan Rahmawati D. P. (2010), menjelaskan adanya tingkat kesadaran masyarakat dalam perencanaan keuangan keluarga perpektif ekonomi islam. Hasil penelitian ini menjelaskan tingkat kesadaran masyarakat Cempaka Putih Ciputat terhadap perencanaan keuangan menempati tingkat tinggi, menurut data yang diperoleh walaupun rata-rata pendidikan mereka rata-rata tidak mencapai perguruan tinggi tetapi masyarakat ini mendapat pengetahuan dari luar, seperti membaca dan mendengar dari orang lain. Dan menurut Rodhiyah (2012), dalam jurnal yang berjudul Manajemen Keuangan Keluarga Guna Menuju Keluarga sejahtera. Menjelaskan bahwa mengelola keuangan keluarga penting karena keuangan keluarga secara keuantitas dan kualitas dapat bermanfaat bagi keluarga secara maksimal untuk mencapai keluarga yang sejahtera yaitu tercukupi secara materiil dan spirital. Oleh karena itu, dapat dirumuskan hipotesis penelitian sebagai berikut:

H1: Terdapat pengaruh tingkat kesadaran masyarakat tentang perencanaan keuangan keluarga terhadap kesejahteraan.

\section{Model Penelitian}

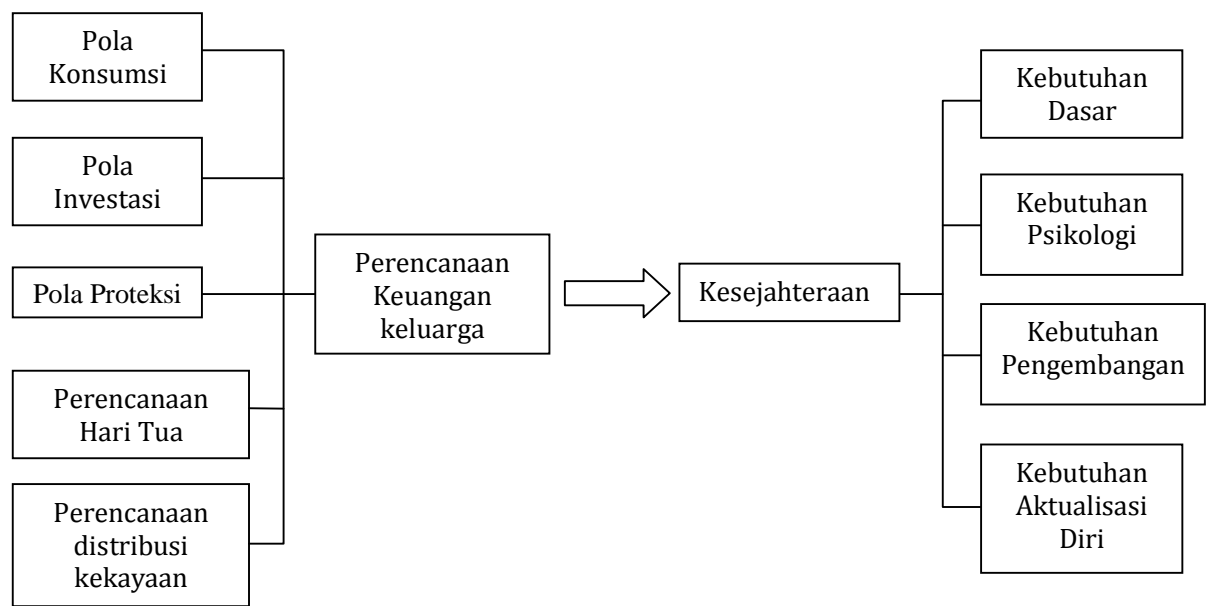


$\mathrm{H}_{\mathrm{o}}$ : Tidak terdapat pengaruh tingkat kesadaran masyarakat tentang perencanaan keuangan keluarga terhadap kesejahteraan.

H1: Terdapat pengaruh tingkat kesadaran masyarakat tentang perencanaan keuangan keluarga terhadap kesejahteraan.

\section{METODE PENELITIAN}

Penelitian ini merupakan penelitian causalexplanatory. Populasi dalam penelitian ini adalah seluruh keluarga komplek Bumi Cipacing Permai (BCP), Jatinangor. Jumlah sampel yang digunakan menggunakan penentuan jumlah sampel minimum. Untuk menentukan sample minimum digunakan pendekatan Slovin, dengan rumus sebagai berikut:

$n=\frac{N}{1+N e^{2}}$

Di mana:

$\mathrm{n}=$ jumlah sample minimal

$\mathrm{N}=$ jumlah populasi

$\mathrm{e}=$ persentase kelonggaran ketelitian karena kesalahan pengambilan sample.

Perhitungan sample:

$\mathrm{N}=\frac{520}{1+520(0,05)^{2}}=226,09$

Jadi, jumlah sampel minimal yang harus di ambil adalah 226,09 yang jika di bulatkan akan menjadi 230. Dengan demikian 226,09 tidak di bulatkan menjadi 225. Ji ka di bulatkan ke bawah jumlah sampel minimalnya tidak dapat terpenuhi karena masih kurang sebesar 1,09. Sample dalam penelitian ini adalah 230 keluarga Komplek Bumi Cipacing Permai (BCP), Jatinangor.

Teknik pengumpulan data yang digunakan adalah sumber Primer. Peneliti di dapat langsung dari masyarakat sendiri yaitu warga Komplek Bumi Cipacing Permai (BCP), Jatinangor. Jenis teknik pengumpulan data yang digunakan adalah dengan survei kuesioner. Kuesioner yang digunakan adalah kuesioner tertutup dimana dalam kuesioner ini, jawaban sudah disediakan oleh peneliti sehingga responden tinggal memilih. Karena jawaban telah disediakan oleh peneliti sehingga jawabannya akan sesuai dengan kebutuhan dalam riset. Uji validitas dan uji realibilitas, uji normalitas dan uji asumsi klasik juga dilakukan sehingga hasil penelitian tepat.

\section{Uji Regresi Sederhana}

Persamaan regresi adalah sebagai berikut:

$\mathrm{Y}=\mathrm{a}+\mathrm{bX}$

Dimana :

$\mathrm{a}=$ Konstanta atau intercept (merupakan nilai Y bila $\mathrm{X}=0$ ).

$\mathrm{b}=$ Koefisien regresi atau slope (kemiringan dari garis regresi: kenaikan atau penurunan $Y$ untuk setiap perubahan satu satuan $\mathrm{X}$ ).

$\mathrm{X}=$ Variabel independen atau variabel bebas (variabel yang mempengaruhi).

$\mathrm{Y}=$ Variabel dependen atau variabel terikat (variabel yang dipengaruhi).

\section{HASIL DAN PEMBAHASAN}

\section{Uji Validitas dan Reliabilitas}

Dari $r$ hitung masing-masing indikator pola konsumsi, pola investasi, pola proteksi, perencanaan distribusi kekayaan, kebutuhan dasar, kebutuhan psikologis, kebutuhan pengembangan, kebutuhan aktualisasi nilai $r$ hitung > r tabel (pada sig 0,05) variabelvariabel tersebut dinyatakan valid. Yang artinya butir-butir dalam suatu daftar (konstruk) pernyataan yang dijabarkan dalam kuesioner dapat mengukur atau mendefinisikan variabel yang di teliti.

Tabel 1: Reliabilitas Perencanaan Keuangan Keluarga

\begin{tabular}{lcccc}
\hline \multicolumn{1}{c}{ Variabel } & N of Items & Cronbach $\boldsymbol{\alpha}$ & Kriteria & Kesimpulan \\
\hline Pola Konsumsi & 15 & 0.878 & 0.60 & Reliabel \\
Pola Investasi & 11 & 0.712 & 0.60 & Reliabel \\
Pola Proteksi & 4 & 0.765 & 0.60 & Reliabel \\
Perencanaan Hari Tua & 3 & 0.740 & 0.60 & Reliabel \\
Perencanaan Distribusi Kekayaan & 2 & 0.796 & 0.60 & Reliabel \\
\hline
\end{tabular}

Sumber : Data Diolah 
Tabel 2: Reliabilitas Kesejahteraan

\begin{tabular}{lcccc}
\hline \multicolumn{1}{c}{ Variabel } & N of Items & Cronbach $\boldsymbol{\alpha}$ & Kriteria & Kesimpulan \\
\hline Kebutuhan Dasar & 6 & 0.864 & 0.60 & Reliabel \\
Kebutuhan Psikologis & 8 & 0.653 & 0.60 & Reliabel \\
Kebutuhan Pengembangan & 5 & 0.818 & 0.60 & Reliabel \\
Kebutuhan Aktualisasi Diri & 2 & 0.649 & 0.60 & Reliabel \\
\hline
\end{tabular}

Sumber : Data Diolah

Variabel pola konsumsi, pola investasi, pola proteksi, perencanaan hari tua, dan perencanaan distribusi kekayaan menunjukkan nilai Cronbach's Apha > 0,60 sehingga variabel dinyatakan reliabel. Yang artinya hasil pengukuran relatif konsisten dari waktu ke waktu.

Variabel kebutuhan dasar, kebutuhan psikologis, kebutuhan pengembangan, dan kebutuhan aktualisasi diri nilai Cronbach's Apha > 0,60 sehingga variabel dinyatakan reliabel. Yang artinya hasil pengukuran relatif konsisten dari waktu ke waktu.

\section{Hasil Uji Asumsi Klasik}

\section{Hasil uji normalitas}

Dari hasil output, dapat diketahui bahwa data secara keseluruhan (dilihat dari nilai residual) menghasilakn nilai Asymp. sig. di atas alpha yaitu $0,028>0,01$ artinya data terdistribusi normal. Jadi, data sample berasal dari populasi yang berdistribusi normal.

\section{Hasil uji regresi sederhana}

\section{Pengujian Model Regresi}

One-Sample Kolmogorov-Smirnov Test

\begin{tabular}{|c|c|c|c|}
\hline & & & $\begin{array}{l}\text { Unstandardiz } \\
\text { ed Residual }\end{array}$ \\
\hline $\mathrm{N}$ & & & 230 \\
\hline Normal Parameters & $a, b$ & Mean & .0000000 \\
\hline & & Std. Deviation & .30187225 \\
\hline Most Extreme & & Absolute & .097 \\
\hline Differences & & Positive & .097 \\
\hline & & Negative & -.083 \\
\hline Kolmogorov-Smirno & & & 1.464 \\
\hline Asymp. Sig. (2-tailec & & & .028 \\
\hline
\end{tabular}

a. Test distribution is Normal.

b. Calculated from data.

\begin{tabular}{|c|c|c|c|c|c|c|}
\hline \multicolumn{7}{|c|}{ ANOVA $^{b}$} \\
\hline \multicolumn{2}{|c|}{ Model } & $\begin{array}{l}\text { Sum of } \\
\text { Squares }\end{array}$ & $d f$ & Mean Square & $\mathrm{F}$ & Sig. \\
\hline \multirow[t]{3}{*}{1} & Regression & 19.181 & 1 & 19.181 & 209.573 & $.000^{a}$ \\
\hline & Residual & 20.868 & 228 & .092 & & \\
\hline & Total & 40.050 & 229 & & & \\
\hline
\end{tabular}

a. Predictors: (Constant), RATA_PKK

b. Dependent Variable: RATA_K

$\mathrm{H}_{\mathrm{O}}=$ Model penelitian tidak fit

$\mathrm{H}_{1}=$ Model penelitian fit (dapat meramalkan $\mathrm{Y}$ )

Tingkat signifikan $=\alpha=0,05$

Uji signifikan $=\mathrm{p}$ value $\leq \alpha=0,000 \leq 0,05 \Rightarrow \mathrm{H}_{\mathrm{o}}$ ditolak 
Kesimpulan: $\mathrm{H}_{\mathrm{o}}$ ditolak, model penelitian fit (dapat meramalkan Y). Model regresi dapat digunakan untuk memprediksi perubahan kesejahteraan keluarga Komplek BCP, Jatinangor. Jadi, Tingkat kesadaran masyarakat dalam perencanan keuangan keluarga berpengaruh terhadap kesejahteraan.

\section{Koefisien Determinasi}

Pada tabel model summary dibawah, dapat di lihat dari kolom Adjusted R Square $=0,479$ $(47,90 \%)$ menunjukkan bahwa kesejahteraan dapat dipengaruhi oleh tingkat kesadaran masyarakat dalam perencanaan keuangan keluarga sebesar 47,90\%.

Kesimpulan: Model summary/besarnya pengaruh Perencanaan Keuangan Keluarga terhadap Kesejahteraan 0,479 atau 47,9\%; sedangkan sisanya $100 \%-47,9 \%=52.1 \%$ dipengaruhi oleh faktor-faktor lain di luar model penelitian.

\section{Pengujian Hipotesis}

Untuk Variabel kesejahteraan $\Rightarrow p$ value $<\alpha=$ $0,000<0,05$

Interpretasi: $\mathrm{H}_{\mathrm{o}}$ ditolak

Kesimpulan: Tingkat kesadaran masyarakat dalam perencanaan keuangan keluarga berpengaruh terhadap kesejahteraan.

Persamaan regresi:

$\mathrm{Y}=\mathrm{a}+\mathrm{bX} \Rightarrow \mathrm{Y}=2,046+0,584 \mathrm{X}$

$\mathrm{Y}=$ Kesejahteraan

$\mathrm{X}=$ Perencanaan Keuangan Keluarga

$\mathrm{a}=$ Konstanta, artinya ketika Perencanaan Keuangan Keluarga sebesar 0, maka Kesejahteraan memilliki rata-rata nilai sebesar 2.046.

$\mathrm{b}=$ Koefisien regresi Perencanaan Keuangan Keluarga, artinya ketika Perencanaan Keuangan Keluarga mengalami kenaikan satu satuan, maka Kesejahteraan mengalami kenaikan sebesar 0.584 atau $58,4 \%$.

\section{Pembahasan}

Hasil dari analisis yang dilakukan dinyatakan sebagian besar responden bekerja sebagai pegawai swasta yaitu sebesar $(30,44 \%)$; sebagian besar responden memiliki jumlah keluarga sebanyak 4 anggota $(61,74 \%)$; sebagian besar responden memiliki sistem pembayaran gaji bulanan $(81,30 \%)$; sebagian besar responden yang memiliki pendidikan terakhir SLTA/SMA $(50,00 \%)$ dan tidak kalah besarnya dengan kepala keluarga yang memiliki pendidikan terakhir Perguruan tinggi/akademik (48,70\%); sebagian besar responden memiliki jumlah keluarga keluarga yang bekerja sebanyak 1 anggota $(52,17 \%)$; sebagian besar responden memiliki 2 orang anak yang masih bersekolah (38,26\%); dan sebagian besar responden memiliki pola makan 3 kali sehari $(91,30 \%)$.

Kemudian melakukan pengujian untuk memastikan apakah data yang digunakan dalam penelitian ini telah memenuhi syarat item-item pertanyaan dimana item pertanyaan dalam penelitian harus dapat mengukur variabel yang diteliti (Valid) dan juga harus konsisten (Reliabel) (Sunjoyo dkk, 2012). Dari data yang diperoleh, dilakukan uji validitas dan reliabilitas terlebih dahulu. Hasil uji validitas menunjukkan seluruh indikator perencanaan keuangan dan kesejahteraan dinyatakan valid, maka semua variabel dapat digunakan untuk tahap penelitian selanjutnya. Hasil uji reliabilitas menunjukkan seluruh indikator perencanaan keuangan dan kesejahteraan dinyatakan reliabel, maka data menunjukkan seluruh jawaban responden konsisten atau stabil dari waktu ke waktu. Kemudian melakukan Uji Asumsi Klasik untuk menunjukkan bahwa data telah berdistribusi normal. Hasil Uji Normalitas menunjukkan bahwa data dinyatakan normal karena nilai sig $=0,028>0,01$. Berdasarkan hasil pengujian regresi sederhana, terdapat pengaruh tingkat kesadaran masyarakat dalam perencanaan keuangan keluarga terhadap kesejahteraan.

Model Summary

\begin{tabular}{|l|r|r|r|r|}
\hline Model & $\mathrm{R}$ & $\mathrm{R}$ Square & $\begin{array}{c}\text { Adjusted } \\
\text { R Square }\end{array}$ & $\begin{array}{c}\text { Std. Error of } \\
\text { the Estimate }\end{array}$ \\
\hline 1 & $.692^{\mathrm{a}}$ & .479 & .477 & .30253 \\
\hline
\end{tabular}

a. Predictors: (Constant), RATA_PKK 
Coefficients

\begin{tabular}{|rl|r|r|c|c|c|}
\hline \multirow{2}{*}{ Model } & & \multicolumn{2}{|c|}{$\begin{array}{c}\text { Unstandardized } \\
\text { Coefficients }\end{array}$} & $\begin{array}{c}\text { Standardized } \\
\text { Coefficients }\end{array}$ & & \\
\cline { 3 - 5 } & & \multicolumn{1}{|c|}{$\mathrm{B}$} & Std. Error & \multicolumn{1}{c|}{ Beta } & \multicolumn{1}{c|}{$\mathrm{t}$} & \multicolumn{1}{c|}{ Sig. } \\
\hline 1 & (Constant) & 2.046 & .129 & & 15.877 & .000 \\
& RATA_PKK & .584 & .040 & .692 & 14.477 & .000 \\
\hline
\end{tabular}

a. Dependent Variable: RATA_K

\section{SIMPULAN}

Mayoritas kepala keluarga memiliki pekerjaan yaitu 217 sampel warga dari 230 sampel, hanya 13 keluarga yang mengandalkan gaji pensiunan dan tidak ada kepala keluarga yang tidak bekerja. Sehingga setiap keluarga memiliki penghasilan yang dapat digunakan untuk memenuhi kebutuhan sehari-hari. Anggota keluarga yang bekerja sebagian besar keluarga hanya kepala keluarga saja, hal ini menunjukkan sebagian besar keluarga hanya mengandalkan gaji dari kepala keluarga untuk memenuhi kebutuhan hidup. Sisanya ada beberapa anggota keluarga yang bekerja untuk membantu kepala keluarga memenuhi kebutuhan ekonomi. Sistem pembayaran gaji sebagian besar kepala keluarga bulanan, hal ini menunjukkan bahwa perencanaan keuangan setiap keluarga sudah terlaksanakan walaupun hanya pada tahap pola konsumsi karena keluarga yang memiliki sistem pembayaran gaji bulanan harus melakukan perencanaan agar gaji yang di peroleh dapat memenuhi kebutuhan sehari-hari hingga mendapatkan pembayaran gaji bulan berikutnya.

Mayoritas sebuah keluarga di Komplek BCP terdiri dari 4 anggota keluarga dan hal ini menunjukkan bahwa sebagian besar keluarga tidak memiliki tanggungan yang terlalu besar untuk kebutuhan sehari-hari seperti keluargakeluarga terdahulu yang memiliki anak hingga belasan. Pendidikan terakhir mayoritas kepala keluarga adalah SLTA/SMA dan Perguruan tinggi/akademik yaitu $98,7 \%$, hal ini menunjukkan sebagian besar keluarga memiliki pemahaman bahwa pendidikan itu penting. Oleh sebab itu, meskipun hanya sedikit anggota keluarga setiap warga keluarga. Tetapi setiap keluarga memiliki anak yang masih sekolah sebesar $76,09 \%$ dan $23,91 \%$ keluarga yang tidak memiliki anak yang masih sekolah dikarenakan anak belum usia sekolah atau sudah lulus sekolah, hal ini menunjukkan bahwa masih banyak keluarga yang memiliki tanggungan jangka panjang yang harus terpenuhi. Oleh sebab itu, diperlukannya melakukan perencanaan keuangan agar pengeluaran dapat lebih terkontrol agar dapat memenuhi semua kebutuhan dan bisa menabung atau melakukan investasi untuk hari tua.

Mayoritas keluarga sudah memiliki pola makan 3 kali sehari, hal ini menunjukan sebagian besar telah memiliki keuangan yang cukup baik karena telah memenuhi kebutuhan dasar.

Berdasarkan hasil pengujian secara regresi sederhana terdapat pengaruh tingkat kesadaran masyarakat dalam perencanaan keuangan keluarga terhadap kesejahteraan. Hubungan kedua variabel tersebut cukup erat dan searah.

\section{DAFTAR PUSTAKA}

Aulia (2009). Perencanaan Keuangan Keluarga (Menciptakan Surplus Anggaran dalam Keuangan Keluarga Anda). Yogyakarta: Cakrawala

BKKBN (1993), Petunjuk Teknis Pencatatan dan Pelaporan Pendataan Keluarga Sejahtera Gerakan KB Nasional. Jakarta: BKKBN Pusat.

Budisantoso, I \& Gunanto (2010). Cara Gampang Mengelola Keuangan Pribadi dan Keluarga. Hal: 11. Jakarta: PT Gramedia

Bungkaes, H. R., Posumah, J. H., \& Kiyai, B. (2013). Hubungan Efektivitas Pengelolaan Program Raskin dengan Peningkatan Kesejahteraan Masyarakat di Desa Mamahan Kecapatan Gemeh Kabupaten Kepulauan Talaud. Journal "Acta Diurna" 
Bungkaes, H.R., dkk (2013). Hubungan Efektivitas pengelolaan Program Raskin dengan Peningkatan Kesejahteraan Masyarakat di Desa Mamahan Kecamatan Gemeh Kabupaten Kepulauan Talaud. Journal "ACTA DIURNA".

Departemen Pendidikan Nasional (2005). Kamus Besar Bahasa Indonesia. Jakarta: Balai Pustaka.Departemen Pendidikan Nasional (2008).

Hidayat, Taufik (2010). Financial Planning Mengelola \& Merencanakan Keuangan Pribadi dan Keluarga. Jakarta Selatan: Mediakita

Iskandar, dkk (2010). Faktor-faktor yang Mempengaruhi Kesejahteraan Keluarga. Sumatra Utara: Universitas Sumatra Utara.

Kamus Besar Bahasa Indonesia Pusat Bahasa. Jakarta: PT.Gramedia Pustaka Utama.

Khurniatun, Sri (2009). Cerdas \& Cerdik Mengelola Uang. Jakarta: Trans Media.

Pratiwi, Rahmawati D. (2010). Tingkat Kesadaran Masyarakat dalam Perencanaan Keuangan Keluarga Perspektif Ekonomi Islam (Studi pada masyarakat kelurahan Cempaka Putih Ciputan. Skripsi. Jakarta: UIN Syarif Hidayatullah.

Rodhiyah (2012). Manajemen Keuangan Keluarga Guna Menuju Keluarga Sejahtera. Semarang.

S, Henky L. \& Ida (2010). Pencegahan Perilaku Compulsive Buying Pengguna Kartu Kredit dengan Perencanaan
Keuangan Pribadi. Bandung: Fakultas Ekonomi, Universitas Kristen Maranatha.

Senduk, Safir (2009). Mengelola Keuangan Keluarga. Jakarta: PT. Elex Media Komputindo

Soekanto, S (1995). Sosiologi Suatu Pengantar. Hal 162. Jakarta: PT. Raja Grafindo Persada.

Solso, Robert. L., Dkk (2007). Psikologi Kognitif. Jakarta: Erlangga

Sugiharto, Eko (2007). Tingkat Kesejahteraan Masyarakat Nelayan Desa Benua Baru Ilir Berdasarkan Indikator Badan Pusat Statistik (The Welfare Level of Fisherman Society of Benua Baru Ilir Village Based on Badan Pusat Statistik Indicator. EPP. Vol.4. No.2: 32-36. Samarinda: FPIK Unmul

Sunjoyo. Setiawan, R. Carolina, V. Magdalena, N. Kurniawan, A. (2013). Aplikasi SPSS untuk Smart Riset (Program IBM SPSS 21.0). Edisi Pertama, Bandung: Penerbit Alfabeta.

Warsono (2010). Prinsip-prinsip dan Praktik Keuangan Pribadi. Volume 13, No 2.

Wibawa, H.K. (2003). Perencanaan Keuangan Keluarga. Jakarta: Salemba Empat.

Yohnson (2004). Peran Universitas di Surabaya dalam Meningkatkan Jumlah Keluarga Mapan di Surabaya (Seri Penelitian Keuangan Keluarga). Jurnal Manajemen \& Kewirausahaan Vol. 6, No.1: 54-71. Surabaya: Universitas Kristen Petra. 